
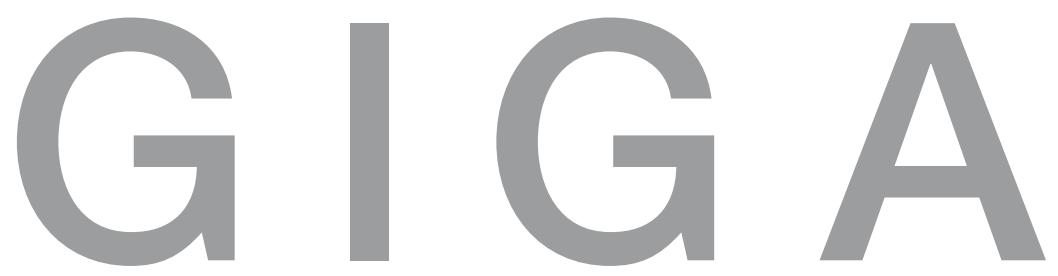

Working

German

Institute of Global and Area Studies Papers

Leibniz-Institut für Globale und Regionale Studien

GIGA Research Programme:

Violence, Power and Security

Breaking the "Insecurity Trap"?

How Violence and Counter-violence are Perpetuated in Elite Power Struggles

Andreas Mehler

$\mathbf{N}^{\circ} 87$

September 2008 


\section{GIGA Working Papers}

Edited by the

GIGA German Institute of Global and Area Studies /

Leibniz-Institut für Globale und Regionale Studien.

The Working Paper Series serves to disseminate the research results of work in progress prior to publication in order to encourage the exchange of ideas and academic debate. An objective of the series is to get the findings out quickly, even if the presentations are less than fully polished. Inclusion of a paper in the Working Paper Series does not constitute publication and should not limit publication in any other venue. Copyright remains with the authors. When Working Papers are eventually accepted by or published in a journal or book, the correct citation reference and, if possible, the corresponding link will then be included in the Working Papers website at <www.giga-hamburg.de/workingpapers $>$.

GIGA research unit responsible for this issue:

Research Programme: "Violence, Power and Security"

Editor of the GIGA Working Paper Series: Martin Beck < beck@giga-hamburg.de>

Copyright for this issue: (C) Andreas Mehler

English copy editor: Melissa Nelson

Editorial assistant and production: Kerstin Labusga, Vera Rathje

All GIGA Working Papers are available online and free of charge on the website $<w w w$. giga-hamburg.de/workingpapers $>$. Working Papers can also be ordered in print. For production and mailing a cover fee of $€ 5$ is charged. For orders or any requests please contact: E-mail: workingpapers@giga-hamburg.de

Phone: ++49 (0)40 - 42825 - 548

The GIGA German Institute of Global and Area Studies cannot be held responsible for errors or any consequences arising from the use of information contained in this Working Paper; the views and opinions expressed are solely those of the author or authors and do not necessarily reflect those of the Institute.

GIGA German Institute of Global and Area Studies /

Leibniz-Institut für Globale und Regionale Studien

Neuer Jungfernstieg 21

20354 Hamburg

Germany

E-mail: info@giga-hamburg.de

Website: www.giga-hamburg.de 


\title{
Breaking the "Insecurity Trap"? \\ How Violence and Counter-violence are Perpetuated in Elite Power Struggles
}

\begin{abstract}
Half a century after independence, African elites, at least those in conflict-ridden countries, often live in constant fear for their life. Real or invented coup attempts, political assassinations, beatings of opposition leaders, the distribution of death lists, etc. have a profoundly traumatizing and self-perpetuating effect. Purges, not least in the security apparatus, are not uncommon, particularly after changes in government, be they peaceful or violent. These purges come at a cost: the excluded elites are frequently tempted to use violence to come back into the "dining room"-and the excluding government tries to prevent reentry by all means.

This contribution draws a dense picture of elite (in)security in three African countries (Central African Republic, Côte d'Ivoire and Liberia). A comparative analysis of elite security needs and devices is undertaken, permitting the author to draw some preliminary conclusions: The ineffectiveness of state institutions (presidential guards, etc.) in breaking the insecurity trap by providing special elite-protection services is obvious. The record of private security services is most debatable and efforts by international actors need to be looked at more closely: UN peacekeepers can be effective when they are sufficient in number and have the appropriate mandate. The record of French interventions in former colonies has over time become ever more ambivalent and has lost any preventive meaning.
\end{abstract}

Keywords: Africa, elites, security, Central African Republic, Côte d'Ivoire, Liberia

\author{
Dr. Andreas Mehler \\ is a political scientist and Director of the GIGA Institute of African Affairs. \\ Contact: mehler@giga-hamburg.de \\ Website: http/staff.giga-hamburg.de/mehler
}




\section{Zusammenfassung}

\section{Titel: Die „Unsicherheitsfalle“ durchbrechen?}

\section{Untertitel: Wie Gewalt und Gegengewalt in Machtkämpfen der Eliten perpetuiert werden}

Ein halbes Jahrhundert nach der Unabhängigkeit leben die Eliten zumindest der durch Konflikte zerrissenen Staaten in beständiger Lebensangst. Tatsächliche oder erfundene Putschversuche, politische Attentate, das Verprügeln von Oppositionspolitikern, die Verbreitung von Todeslisten etc. haben tief traumatisierende und sich selbst verstärkende Effekte. Säuberungen, vor allem im Sicherheitsapparat, sind nicht unüblich, gerade nach friedlichen oder gewaltsamen Regierungswechseln. Diese Säuberungen produzieren Kosten: ausgeschlossene Eliten sind oft geneigt, Gewalt anzuwenden, um ins "Speisezimmer" zurückzugelangen, und die Regierung versucht, diese Wiederkehr mit allen Mitteln zu verhindern.

Der vorliegende Beitrag zeichnet ein dichtes Bild der (Un)Sicherheit von Eliten in drei afrikanischen Staaten (Zentralafrikanische Republik, Côte d'Ivoire und Liberia). Vorgenommen wird eine komparative Analyse von Bedarfen und Mechanismen der Elitensicherheit, um zu folgenden vorläufigen Ergebnissen zu kommen: offensichtlich ist die Ineffizienz staatlicher Einrichtungen (Präsidialgarden etc.), durch spezifischen Elitenschutz die Unsicherheitsfalle zu durchbrechen. Die Bilanz privater Sicherheitsdienste ist umstritten und die Bemühungen internationaler Akteure müssen näher betrachtet und differenziert werden: UN-Friedenstruppen können effizient sein, wenn sie in ausreichender Zahl und mit dem richtigen Mandat auftreten. Die Bilanz französischer Interventionen in Exkolonien ist dagegen allmählich immer ambivalenter geworden und hat mittlerweile jegliche vorbeugende Wirkung verloren. 


\title{
Breaking the "Insecurity Trap"? \\ How Violence and Counter-violence are Perpetuated \\ in Elite Power Struggles
}

\author{
Andreas Mehler
}

\author{
Article Outline \\ I Introduction \\ II Case Studies on Elite (In)security from a Comparative Perspective \\ III Conclusion
}

\section{Introduction}

When cause and effect can no longer be distinguished, when it has become difficult to know where to start dealing with a problem, and when "more of the same" is the consequence of a calamity, it is not uncommon to talk of a "trap." Many African states' elites are in an insecurity trap, as perpetrators and victims. Taming the political game and playing it according to accepted and enforced rules is arguably what most African politicians would prefer to do. They may, however, believe that they cannot. Paul Collier et al. (2003:10) define what is called a conflict trap: "Once a country has had a conflict it is in far greater danger of further conflict: commonly, the chief legacy of a civil war is another war." In fact, with the help of statistical methods, Collier et al. test a number of correlations and find that the fact that there was a conflict is most conducive to more conflict-more than any other variables tested. The purpose of this paper is to be more precise, focusing on one crucial conflict factor (elite insecurity). A more qualitative design is pursued in order to make it plausible that elites can be confined in an "insecurity trap," suffering from and perpetuating acts which instill ever more distrust and pave the way to the widespread use of violence. 
Distrust may be defined as "a disposition hindering individuals from interacting with others and relying on institutions," and can be seen as the opposite of trust. Bauer and Dobler (2008:2-3), in their effort to better grasp the meaning of the multidimensional phenomenon of trust, first make the general statement that

[t]rust in its most general sense is the assumption that others will act in a particular way. As trust is oriented towards the future and not based on knowledge, people must be willing to interact without a guarantee in trusting other people or institutions. Trust as an attitude depends on experience and expectations and involves a sense of the other's competence, motivation and intentions.

They further distinguish between basic a) social trust, b) personal trust, c) institutional trust, and d) normative trust. For the purpose of this paper, institutional trust is probably essential. According to Bauer and Dobler, with institutional trust "people assume that they can trust a particular institution, for instance that the police will protect them. Trust in a person is institutional when we for instance assume that a civil servant as a representative of state administration will provide the services we have the right to receive." The opposite, institutional distrust, can be easily derived from this definition and may be the outcome of what will be described and analyzed in this contribution. However, some elements of personal trust between top politicians (trust "based on numerous former, personal interactions") may play a role for this analysis as well. It should be stated from the outset that trust/distrust is not seen as the cause of elite insecurity, but rather as an aggravating or prolonging factor of intra-elite struggles.

The paper is structured into two main parts: In the first part, as an integral part of this introduction, a number of clarifications have to be made:

- Who are the elites?

- What do they fear?

- What are their responses?

- How is the insecurity trap constituted?

The second part of the paper describes in some detail the relevant aspects of three conflictridden African countries:

- Central African Republic

- Côte d'Ivoire

- Liberia

All country -cases are presented following the same pattern: 1) elite security needs are described, 2) patterns of elite exclusion are detailed, 3) the available state services are rated, and 4 ) the role of externally based elite protection (private and public) is analyzed. 
Materials used are essentially secondary sources: UN Security Council and media/Internet reports, preferably from local sources. All countries have been visited by the author once (Liberia) or several times.

The second part of the paper is also devoted to a comparative analysis which tests some preliminary hypotheses. What the three countries have in common is the experience of widespread conflict, a high number of elite assassinations, and the traumatizing effects of regime changes. They differ, however, in at least three respects:

- Two countries (Liberia and Central African Republic) are comparatively small, and the size of the elite in both countries is equally small. Côte d'Ivoire is much bigger and has a comparatively large elite. The underlying hypothesis is that this could have an effect on trust/distrust (the smaller the elite, the higher the distrust), and also-in an opposite way-on the ability to provide security (the bigger the elite, the more difficult it is to protect it).

- Central African Republic (CAR) and Côte d'Ivoire are former French colonies and for a long time undertook intense military cooperation with France, thereby affecting expectations of outside intervention in the case of violent attempts to overthrow governments. Liberia was not a French colony (underlying hypothesis: French military presence leads to improved elite security).

- The crises of Liberia and Côte d'Ivoire received relatively strong international attention, also during the search for peace agreements, and translated into strong UN engagements, while CAR only seriously entered the international agenda after the Darfur crisis and more decisively only in 2007. The "international engagement factor" in peacemaking and security provision can be described and analyzed with CAR as the control case (weak international engagement leads to higher elite insecurity). ${ }^{1}$

This means that the "small-size" factor, the "French factor," and the "UN factor" will be particularly tested according to the comparative perspective.

The third part of this paper is a sort of conclusion. The effects of the above factors are rated and alternative explanations are briefly developed.

\section{Who Are the Elites?}

It is not obvious who belongs to the elite of a given African country; sometimes selfascription may differ from what can be "objectively" said about the composition of an elite. Above all, there are different understandings of the elite. The academic literature detailing definitions of elites can be distinguished into roughly three categories: a sociological view on elite dominance dealing with elites as the top social stratum (e.g. Mills, for Africa: Bayart

1 Note that Lambach (2007: 12) explores the usefulness of the oligopoly of violence paradigm for different types of post-conflict countries with the main distinction being "intervention" versus "non-intervention." 
1989); studies on the importance of a narrower group of people influencing the outcome of democratic transitions (e.g. Quantin 1995, Villalón/Von Doepp 2005), sometimes simply reinventing themselves in this process (Daloz 1999, Hillebrand 1993); and more systemic or functional definitions of an elite as those who run a country in different sectors of the polity (e.g. Dahrendorf). This last understanding is essential for what is looked at in this contribution. A second step consists of determining an appropriate way to identify this functional elite without being arbitrary. Good analysis on the functional elites of any African country is rare. In a once rather influential book on Cameroonian elites, Jean-Flambeau Ngayap (1983: 13f) makes a well-informed case for the existence ofa total number of about 1,000 persons who make up the entire elite of such a medium-sized, medium-income country in Central Africa. He includes the functional elites of the state: members of government and parliament, territorial administration down to the prefect level, government services down to the director's level, high-ranking judges and prosecutors, military officers down to the colonel rank, the mayors of the three main cities, ambassadors, para-state directors and private business tycoons (220), as well as top party officials. (Not included, but debatable would be the senior traditional authorities and top religious authorities). This methodological approach is replicated to some extent here. Ngayap's analysis was written in the one-party era when counter-elites and civil society leaders could not play a prominent role. The number may be extended by about 200 if those individuals are added to the list (to be generous) and by taking into account the constant expansion of the government under President Biya. This number of 1,200 in the Cameroonian case may be taken as a rough estimate of the size and composition of the elite of each of Central African Republic (CAR), Côte d'Ivoire, and Liberia.

Another qualification is necessary with regard to elite security: the strategies of the rich and poor to provide themselves with security are usually different. In their study of private security companies in Kenya, Mkutu and Sabala (2007: 400) note that

"[t]he wealthy are turning their homes into fortresses, hiring security guards with elaborate alarm systems, and wiring their walls with electrified fences capped with razor and electric wires, while the poor in the slums hurry home in matatus before sunset or hire vigilantes such as Mungiki and the Taliban."

Mkutu and Sabala acknowledge that "even ministers and foreign diplomats have been targets of thefts and shootings." It is evident from this quote that a) in a context of poverty rich people attract criminals and b) in a context of state weakness they might not get sufficient protection from the police services. Hence, they turn to private services. However, while elites usually are rich, they are not identical with the rich. They have particular security concerns, different from those of "the rich" and largely linked to their political function; they therefore turn to specialized (semi)private services when they do not trust public security forces. 


\section{What Do They Fear?}

It is true, elites are usually better equipped and have other opportunities to protect themselves than ordinary people. On the other hand, they may be visible targets of criminal acts-and above all politically motivated violence. Intra-elite confrontation including physical violence is a common phenomenon in Africa. When talking about trust as an essential element of security-or the subjective side of security-it might be tempting to analyze intra-elite trust rather than what the common citizen has to say about it. ${ }^{2}$

Intra-elite distrust may be traced back to the origins of a conflict escalation pattern familiar in Africa: the breakdown of a neopatrimonial regime. The main characteristics of neopatrimonialism are the absence of a division between the private and the public sphere and the dominance of clientelism over formal procedures, although rational-legal facades persist (Médard 1977: 67-74, Engel/Erdmann 2007). Elite accommodation is a function of the distribution of sinecures in such a system. The well-embedded economic deficiencies of neopatrimonial systems, the dynamics of the education system (multiplication of elite aspirants), and unfavorable world market conditions for major export commodities moved numerous African regimes close to implosion as early as the 1980s. The incapacity to maintain the logic of distribution led to conflicts-sometimes violent ones (Allen 1999). ${ }^{3}$ One main aspect of the elite-insecurity nexus is the exclusion paradigm. Exclusion in the neopatrimonial context means shutting out elite members from the sinecure system to either maintain or maximize one's own profits. The excluded can react differently, but more often than not they will try to reverse their fate.

Elites do encounter more specific and immediate security challenges. It would be wrong to underestimate the exclusive elite's fear of facing armed insurrection by the excluded. Their fear is justified. But to be in opposition may be even more dangerous. For example, opposition politicians might be explicitly targeted by "death squadrons." Top opposition members in a country such as Burundi or Chad are indeed in constant danger. The so-called "selective genocide" against Hutu elites (from the top level down to teachers) in Burundi in 1972 (Lemarchand/Martin 1974) is probably the best-known attempt to wipe out an entire ethnic elite. The story does not end here: The historic disaster for the Front pour la Démocratie au Burundi (FRODEBU) was the assassination of the first freely elected Hutu

2 In different papers, I have argued that the lack of knowledge about the security perceptions of the larger population in Africa is most dramatic and needs to be overcome by concentrating research here. However, it would be wrong not to acknowledge that elite security concerns are very relevant too. This paper focuses on one side of the coin, without claiming that it is the only one that needs to be carefully polished in order to clearly discern the embossment of "African security."

3 Mkandawire (2002: 185) rightly points to some fluidity in this argument, as neopatrimonial regimes "have taken a wide range of turns, including violent collapse, bureaucratisation and democratisation." It may be argued that others have survived more or less unaltered, although the "spoils system" was at times overstretched by using electoral manipulation and repression (Cameroon and Gabon would be cases to be considered). However, the mechanism of declining patronage capacities plus exclusion is too common a story to be neglected. 
president Melchior Ndadaye and several other leading party representatives by army officers in October 1993. Ongoing political assassinations produced a heavy toll in the FRODEBU camp, $23 \mathrm{MPs}$ from the party were murdered during the first four years after the 1993 elections. In August 2007 grenades hit the homes of three members of parliament and the residence of the vice chairman of FRODEBU. ${ }^{4}$ More recently, in February 2008, 46 opposition MPs wrote an open letter to UN Secretary-General Ban Ki-moon claiming that a death list of 350 opposition members has been drawn up and asking for protection. The outcry came after the leader of Burundi's main opposition party, again the FRODEBU, was severely wounded in a grenade attack which killed his wife and baby. ${ }^{5}$ Those experiences are dramatic and hardly compare with the experiences of politicians in "the" West; they must be traumatizing for top elite members.

Political murder is certainly not particular to Africa south of the Sahara (think about Sri Lanka, recent attempts in East Timor, etc.), but in some countries it seems to be a distinct feature of politics. The history of Chad could be written as a history of political assassinations (from Outel Bono via Abbas Koti to Laokein Barde). When Idriss Déby's regime was nearly swept away by a rebel attack on N’Djaména in February 2008, it provided an opportunity for a still not fully elucidated action against the main opposition leaders. While one leader soon reappeared, another continued to hide and a third one was believed to have been killed by the presidential guard. ${ }^{6}$

\section{What Are Their Responses?}

One essential question is what kind of protection elites need in Africa. Is it protection from crime or rather from politically motivated violence? There is no doubt that the big gap in the standard of living of the few rich and the masses is attracting envy. In this context, protection from burglary is a mere necessity. But in conflict-ridden countries, that is, approximately one-third of all sub-Saharan countries, these threats are minor compared to the threats from fellow elite members (and can mostly be prevented). Private security companies-and, for government ministers and the like, specialized units of the official security forces - rather effectively guard the properties of elite members in "normal" times. When demonstrations turn violent, the targets of the popular furor are frequently symbols of the state, party headquarters, public buildings, and police stations. While the message of these acts is directed at elites, they are rarely immediate victims themselves. After all, the most life-threatening dangers do not come from the ordinary citizens. And elites are well aware of this.

\footnotetext{
4 Radio Publique Africaine, Bujumbura, 20 August 2007, as reported by BBC Monitoring Global NewslineAfrica Political, 21 August 2007.

5 www.bbc.co.uk, 29 Feburary 2008 (access 1 March 2008).

6 AFP, 29 February 2008 (access via www.izf.net, 2 March 2008).
} 
African elites do invest heavily in security; those in top power positions frequently establish parallel government structures which control each other, establish personal militias, and secure outside support (private, bilateral, or international). However, this can be problematic when those outsiders have, at least partly, their own agenda. The specific devices of the presidential security detail may need more attention than they usually get and are therefore a second aspect of interest in this contribution. One of the favorite topics of specialized organs such as Africa Confidential and La Lettre du Continent dealing with the more discrete side of African affairs is presidential security. Some of the information given is hearsay at best, difficult to verify and by its very nature discrete. What is evident is the considerable attention given to the question of the personal security of those in power by those people themselves. However, it is also true that a larger segment of the population may profit from elite protection. A spectacular case was the outsourcing of security by the Sierra Leone government to a commercial enterprise in 1995. Arguably, the entire population of the capital Freetown profited. The effectiveness of private services may, however, only be upheld in the short term (Holmqvist 2005: 12f).

In less spectacular cases, presidential security might be the domain of a third country. Specialists in procuring this service can be found in, for example, France, Belgium, Israel, South Africa, and Morocco. Usually, the profit-making side of this connection is highlighted in reports:

in Angola, International Defense and Security (IDAS), the Belgium-Dutch company, obtained the rights to a diamond concession larger than Belgium in exchange for its security services. In Congo-Brazzaville, Levdan, an Israeli firm, saw itself awarded half of the shares of the Marine III oil production permit by the Lissouba Government for having trained the Zulu militia. ${ }^{7}$

The exact deal or the price of such an agreement is systematically kept secret, and this contribution cannot shed more light on this aspect. Whether those services are more statesponsored or commercially driven is also not clear. But for the purpose of this study it is noteworthy that many African heads of state have more trust in outsiders than in their own security apparatus when it comes to their immediate personal security. It is, for example, common knowledge that in the case of Cameroon, Israeli specialists are in place to guarantee President Biya's immediate personal security, though more tangible information is difficult to obtain.

In the next concentric circle around the head of state, specialized government forces are usually responsible for guarding core public buildings; they receive special assignments and are believed to be ultra-loyal. These forces might be called presidential guards or republican guards or something similar and can form a substantial part of the overall state security forces. Presidential guards are frequently better paid and better equipped than the rest of

7 Memorandum: Towards a Spiral of Violence? The danger of privatising risk management of investments in Africa, October 2000 www.miningwatch.ca/updir/Memorandum-final-en.pdf, access 12 June 2008. 
the security apparatus, making it particularly interesting to be recruited in such an elite corps. Accusations that presidents favor fellow tribesmen for recruitment into their own presidential guard are not rare. This recruitment pattern is highly problematic. A change of regime engendering a change in the ethnic identity of the head of state may then mean that the presidential guard has to be both politically and ethnically purged, creating a number of difficult-to-handle losers-frequently well trained, once particularly privileged, and now sidelined or kicked out and frustrated. This is a group to be watched, and a good number of new heads of state are nervous about such groups.

\section{What Constitutes the Elite Insecurity Trap?}

The emergence of an exclusive government elite in the neopatrimonial context is an important conflict factor. The escalation mechanism is as follows: After a change in government or as a result of a shrinking political arena, key decision-making positions in the presidency, cabinet, parliament, military, and judiciary do not-or no longer-include the elite representatives of major identity groups. In addition, and on a lower level, most jobs in the civil service, police force, and army are reserved for members of one or two specific social or identity groups. Institutional devices may be established to guarantee a more permanent exclusion of counter-elites (for example, high thresholds to win mandates in parliament; constitutional provisions tailor-made to prohibit specific candidates from standing, such as age -limits; etc.).

The already privileged circles usually have better means for keeping their jobs or accessing opportunities in times of crisis. Exclusion could become a rational strategy for them. Since exclusion is not only a rational but also a radical strategy employed by those in power, responses tend to be radical as well, leading to a rapid deterioration of intergroup relations and to polarization (Lemarchand 2001). There haven't always been such dramatic consequences with a change of government, but a clear escalation pattern can be identified: At first, a specific group might simply enjoy privileged, but not exclusive access to strategic positions. Gradually, the government payroll is "homogenized," and only one group is left represented. ${ }^{8}$ If elections are held, marginal groups vote unsuccessfully for opposition parties headed by excluded elite groups - or cannot vote for their preferred candidates as they are barred from standing. Hence, the formal political process does not offer a solution for dealing with ever more pressing grievances. Would-be leaders go underground and organize armed challenges to the incumbent regime. Disloyal conduct increases and leads to further polarization. A composite power base of the regime might split, leaving only a small minority in power. In a final stage (not necessarily reached in every case), pogroms and ethnic cleansing begin to occur, representing the triggering event and the entry point into a

8 An example would be the last years of Habyarimana rule in Rwanda, when not only Hutu, but particularly those from his home region, occupied most important positions. 
new level of escalation-at times even including genocide. Due to death threats and the persecution of family members and party adherents (on the side of the excluded) as well as coup attempts and armed rebellion or rumors thereof (on the side of the governing elite), positions are hardened in a spiraling way. When, finally, the arrangements concluded at a dialogue forum (or the like) are not respected, even more profound distrust settles in and become a serious obstacle to a settlement.

\section{Case Studies on Elite (In)security from a Comparative Perspective}

This section will provide more insights into the main aspects of elite security in three countries: Central African Republic, Côte d'Ivoire, and Liberia. In each of the case studies a subsection will be devoted to each of elite security needs, patterns of elite exclusion, state services, and the role of externally based elite protection (whether private or public).

\section{Central African Republic}

\section{Elite Security Needs}

Central African Republic (CAR) is a small country with a small political elite. Virtually everybody knows each other, but this has not led to more trust. CAR elites have good reason to be nervous about their security. A high number of assassinations and further attacks of politicians and their homes have occurred over the last decades. CAR experienced one of the earliest coups in independent Africa (December 31, 1965). The erratic rule of "Emperor" Bokassa $^{9}$ (1966-1979) led to a couple of unpredictable and sometimes atrocious assassinations (including emasculation) of mostly military elites. ${ }^{10}$ Gen. André Kolingba's rule (1981-1993) was not devoid of arbitrary detention, but was largely free of political assassinations. ${ }^{11}$ He faced a coup attempt masterminded by two later presidents of the republic in 1982 (Bozizé/Patassé). With the popularly elected President Ange-Félix Patassé (1993-2003), things got worse again: the second mutiny of a sizable part of the country's army in 1996 provided the pretext for the assassination of former defense minister Christophe Grelombe. Grelombe was not the best-loved man in the country as he was held responsible for some of the worst human rights abuses under Kolingba. But he was murdered together with his son, which made the act look like a more definite attempt at

\footnotetext{
9 David Dacko's rule, 1960-65, was authoritarian and was accompanied by the repression of opposition forces; his second term in office, 1979-1981, was more tame.

10 At least eight high-ranking military officers were killed under Bokassa's rule. In some cases close family members were killed as well, apparently out of fear at facing retaliation from them.

11 The only major elite victim was opposition heavyweight Dr. Conjugo, killed by gendarmes during a protest march in 1991. The direct responsibility of Kolingba could not be established.
} 
exterminating an entire family. ${ }^{12}$ When former prime minister Jean-Luc Mandaba died in a French hospital, followedonly a short time later by his son Hervé, it was interpreted by some as another assassination (poison attack), ${ }^{13}$ although the event was not completely elucidated. Not only politicians were targeted: in 1999 the influential trade union leader Sonny Cole was shot at and arrested by the presidential guard and beaten. ${ }^{14}$

During the failed coup attempt against Patassé in May 2001, a handful of key personnel from the regime were killed, amongst them Gen. Abel Abrou, chief of staff, and Gendarmerie Gen. Njadder Bedaya. But in the following retaliation phase a bigger number of elite members were killed by death squads, among others the member of parliament Théophile Touba and a member of the constitutional court, Sylvestre Omisse, apparently because he had a name which sounded like a Yakoma name (although he was not of Kolingba's ethnic group). In the period that followed the uprising, retaliatory acts targeted all those affiliated with Kolingba. This included friends and family, members of his political party (RDC, Rassemblement Démocratique Centrafricain), and the Yakoma in general. Militia groups affiliated with Patassé "eliminated" several Kolingba sympathizers (while the former president found temporary asylum in Uganda).

The downfall of Patassé was only delayed and came about when his long-standing ally and former chief of staff François Bozizé, chased from his position and suspected of a coup in late 2001, succeeded in taking the capital Bangui in March 2003. Also under Bozizé, several acts of violence against elite members were recorded in the capital. Ex-prime minister Koyambounou was reportedly beaten and threatened with a gun by one of Bozizé's sons; the former was later arrested under corruption charges. Another severe incident took place on March 22, 2005, shortly before the presidential elections, near the residence of André Kolingba. Gun shots were exchanged between the security guards of the former president and unknown elements. The government later declared that soldiers on duty along the Ubangi River had accidentally shot their guns off and that no attempt on the life of Kolingba, a candidate in the elections, had been made. Evidently, the interpretation on the side of Bozizé's opponent was different. ${ }^{15}$

12 Grelombe's assassination was named frequently in the same context as the murder of the prefect of Bozoum, Col. Rehote, with a number of relatives (one younger brother) in 1997 and of Lt. Bodo in Kolingba's home region of Kembe, in 1999. See Sangonet, 22 November 1999.

13 This led to a short uprising by youth in the Boy Raabe neighborhood, a rather serious situation as Mandaba was thought to be the main organizer of the so-called Karako militia. See Sangonet, 13 November 2000, www.sangonet.com/ActualiteC3/Situationtendue14nov00.html.html (access 18 February 2008).

14 International Confederation of Free Trade Unions (ICFTU) online, 11 January 1999, confirmed by Sangonet, 10 February 1999.

15 Source: Radio Centrafrique, Bangui, in French 1300 gmt 23 Mar 05 as reported by the BBC Monitoring Service. 


\section{Patterns of Elite Exclusion}

CAR is a classic example of the terrible dynamics of elite exclusion: One of the features of Patassé's presidency was the sidelining of the followers of the former head of state, Gen. Kolingba. It is true that Kolingba favored his fellow Yakoma in recruiting his army and presidential guard. But the new, democratically elected regime simply proceeded in the opposite way, drawing its new recruits primarily from the home region of President Patassé. This was interpreted-and could well be interpreted-by the old guard as a strategy of exclusion. Exclusion is particularly resented in societies that are based on zero-sum beliefs, which is very much present in the rhetorical formula "partition of the national cake." And ruling elites generally want to reward mainly their own power base. What is frequently not reflected is the "nuisance capacity" of those who are excluded. This can be seen in the case of CAR, where both the 1996/97 mutineers and the perpetrators of the 2001 coup attempt were Kolingba followers. As an initial response to the latter event, the regime demonized Kolingba, the Yakoma, and the RDC in parallel as the source of the conflict. However, the matter soon became more complex. A "mixed judicial enquiry team" was set up in June 2001 with the mission of investigating the rebellion. The investigation was conducted with great zeal by the chief prosecutor and led to the surprising indictment of Defense Minister JeanJacques Demafouth, who was accused of siding with Congolese rebel leader Bemba in order to get rid of Patassé in a potential second coup. ${ }^{16}$ The deadly course of vendetta continued: several of Demafouth's relatives were now arrested. The retaliation pattern was no different when Bozizé defected in November 2001. Elites from his ethnic Gbaya group, like Serge Wafio, vice president of the National Assembly, were arrested and tortured. Whether the motivation of such acts can be found in a strategy of "deterrence" or that of a "preemptive strike" is difficult to assert.

With François Bozizé's violent takeover in March 2003, history again repeated itself: he immediately sidelined Patassé's followers in the security apparatus. Bozizé was well placed to take those decisions as he was the former chief of staff, with insider knowledge about the apparatus. Core elements of Patassé's recruits ended up taking part in the Armée pour la Restauration de la République et la Démocratie (APRD) rebellion in the northwest of the country. Bozizé was lucky that they did not have the time and opportunity to take along modern equipment and weapons. However, there is no doubt that these elements were highly motivated to oust the new regime. This motivation was also strong among the socalled "ex-liberators" who helped Bozizé to take power in March 2003 and were subsequently dismissed. Some of them formed the backbone of the Union des Forces Démocratiques pour le Rassemblement (UFDR) rebellion in the northeast. To be sure, most of those "security specialists" excluded were not members of the elite; this would only be

16 The accusation sounded curious as Bemba's Mouvement de Libération du Congo was in fact a major source of support for Patassé in this phase of history. 
true for the top echelons of the army. It is, however, not without effect that the ousted elites have ousted followers.

The insecurity question was on the agenda of the "National Dialogue" conference held in October 2003 in Bangui. This meeting can be considered an important elite gathering, in which 350 delegates took part. Compared to the Cameroonian elite (estimated at 1,200, see above), the CAR's top decision makers are less numerous, as the state apparatus or the business community are much smaller. A guess would be that maybe only 400-500 people would form the country's elite. Only the Patassé camp did not take part in the "National Dialogue." The participants of the gathering were realistic when enumerating the main reasons for the failure of the national defense forces to assume their mission to provide security and included-somewhat self-critically-"the politicizationof the defense and security forces" and the "use of non-conventional forces." ${ }^{17}$ A preparatory committee for a new "inclusive political dialogue" transmitted its report to President Bozizé on April 24, 2008. Defense and security figure among the most prominent topics for this new elite gathering. And among the approximately 150 potential participants is Jean-Jacques Démafouth, who has presented himself (belatedly) as the driving force of the APRD rebellion. $^{18}$

\section{State Services}

In CAR, Patassé might have had reason not to trust the army (most recently because of the three mutinies in 1996/97), but he made little effort to reform it. Instead he relied on his presidential guard (since 1998 labeled FORSDIR ${ }^{19}$ ), which in turn became much feared by his political rivals and civil society organizations. When the MINURCA ${ }^{20}$ mission head asked for a restraint of FORSDIR functions, Patassé replied, according to the official report, "that FORSDIR was the only loyal and operational arm of the security forces on which he could rely. He categorically stated that he could not take any of the measures recommended by my [the UN Secretary-General's] Special Representative except at risk to his own safety." ${ }^{21}$

Under Bozizé the name of the presidential guard changed again. It was now officially called the Bataillon de protection et de sécurité des institutions (BPSI) and was allegedly responsible for the worst human rights abuses in the provinces. ${ }^{22}$ It[need to specify what "it" is] also meant that this was an elite combat troop; the immediate protection of Bozizé was left to outsiders. The size of the presidential guard has not varied strongly over time: about 750-900 members are currently part of that body.

17 Dialogue national-Commission n³, défense et sécurité (conference document, not dated).

18 www.sangonet.com/afriqg/PAFF/Dic/actuC/newsCARind.html (access 16 June 2008); La Lettre du Continent, 27 September 2007, 6 March 2008, 8 May 2008.

19 Force spéciale de défense des institutions républicaines, later: Unité de Sécurité Présidentielle (USP).

20 Mission des Nations Unies en RCA.

21 See Seventh Report of the Secretary-General on the United Nations Mission in the Central African Republic, 15 July 1999 (S/1999/788), para. 8.

22 Le Monde Diplomatique, 2/2007. 


\section{The Role of Externally Based Elite Protection-Private and Public}

CAR is linked to France by a defense agreement. While in other countries this could be seen as a kind of life insurance for the president and his immediate circle of friends and family, it has certainly been more ambiguous in the case of CAR. The "Barracuda syndrome" (Ngoupande 1997) attests to this. While Bokassa enjoyed substantial French support during most of his reign, he was effectively deposed by the French government when it used troops to fly in his predecessor David Dacko in September 1979 ("opération Barracuda"). Dacko reluctantly took power and voluntarily withered away when André Kolingba was eager to take it again, by force, in a bloodless coup on September 1, 1981, ending a short-lived experience with multiparty democracy. Why did Paris not intervene in 1981? The French government could well argue that the threat did not come from outside; what is more, Dacko himself kind of wanted to resign. Thus, there was no need to activate an existing defense agreement. This argument was much more difficult to justify in the crisis phases during Patassé's rule: why intervene in favor of Patassé during the three mutinies in 1996/97 (with a threat coming from inside) and not in 2002/03 when former chief of staff Bozizé attacked the country from Chad and with obvious Chadian assistance? What is more, Patassé had called for assistance with reference to the defense agreement, but to no avail. And finally, compare this passivity to 2006/07, when France invoked the defense agreement to fight UFDR rebels who were certainly no less nationals or foreigners than Bozizé's fighters who had attacked in 2002/03 (and some of whom were identical). What the balance sheet of French involvement to save CAR regimes shows is that there is no guarantee for those in power that they will be protected simply because there is a defense agreement.

Another protective function for elites was fulfilled by the French embassy. When the Patassé/Bozizé coup failed in 1982, Patassé fled to the French embassy. ${ }^{23}$ It was not by chance that David Dacko's residence was in the immediate vicinity of the embassy. Finally, some of the suspected leaders of the May 2001 coup attempt-such as Capt. Parfait Mbaye (later minister under François Bozizé) - earlier implicated in the mutinies, fled to the French embassy, thus saving their lives.

The role of French instructors, not only in the army but also in the more immediate security apparatus, is certainly not negligible. All CAR presidents have had their immediate security advisors, most notoriously Col. Mantion in the case of Kolingba, who had more than just security functions (ICG 2007: 7-9). Patassé relied on a number of external advisors and alleged mercenaries - the difference might not always be easy to determine. ${ }^{24}$ French

23 Bozizé could flee to Chad, but ended up in Benin, where an armed commando traced him and brought him to Bangui by force. He was imprisoned and tortured (and only freed in 1991).

24 The nine opposition candidates in the 1999 presidential elections (André Kolingba, David Dacko, Abel Goumba, Enoch Derant-Lakoué, Jean-Paul Ngoupande, Charles Massi, Henri Pouzère, Fidèle Gouandjika and Joseph Abossolo) alleged that Patassé would rely on "Yugoslav" and South African mercenaries integrated into the FORSDIR special unit. See their declaration posted on Sangonet, 25 August 1999 (www.sangonet.com, access 2 January 2000). 
officers, retired or active, such as Mantion and the generals Perez and Guillou (La Lettre du Continent, July 19, 2007) or ex-Gendarmerie captain Paul Barril stand out as prominent names. Barril took office as presidential advisor in 1995; later he was in charge of "fighting terrorism." According to the French daily Le Figaro, Barril's power extended beyond the immediate aspect of presidential security; he was allegedly remunerated with money from the secret deals of Patassé. ${ }^{25}$ The already debatable record of Barril's performance was further tarnished after Bozizé managed to take Bangui by force.

Officially, French advisors continued to work in close cooperation with the new head of state, first Gen. Perez, then Gen. Guillou (La Lettre du Continent, September 14, 1996). However, Bozizé seems to have learned a lesson when he looked somewhere else for support with regard to his own personal security. In the early days after his takeover he appealed to Chad's Idriss Déby to send a number of elite troops (allegedly about 150). The problem was that the Chadian elements of the presidential security remained very unpopular in Bangui. A confrontation with the Gendarmerie took place in Bangui on December 7, 2006, during which one Chadian was killed. dementia rumor pas put out that the Chadian security personnel in retaliation would have killed three gendarmes. The government issue a démenti. ${ }^{26}$ South African specialists were later brought in during 2007 to form Bozizé's presidential guard. ${ }^{27}$ An army general had already visited Bangui in February. In August, about 50 South African military personnel arrived. However, Paris and Pretoria later began to harmonize their involvement with the CAR's security forces (ICG 2007: 33, footnote 185; La Lettre du Continent, May 22, 2008). This may have been a move to keep Israel out of the picture; it had reportedly sent inter alia three generals to Bangui in July $2007 .^{28}$

The limited UN mission in CAR (1,350 maximum authorized strength) had an equally restricted mandate, which was only extended to cover electoral assistance (legislative and presidential elections in 1998/99). Security-related aspects were then limited to the security of electoral equipment and international observers. ${ }^{29}$ Interestingly, the 380-person-strong

25 “Patron de la société Secrets, Paul Barril fait la pluie et le beau temps à Bangui. Il a la confiance d'un Patassé au comportement souvent ubuesque. Ainsi, dans sa dernière interview, le président centrafricain confiait son désir de construire un aqueduc reliant Bangui au Proche-Orient... Chargé de protéger l'ancien premier ministre de l'empereur Bokassa Ier, Paul Barril a été bombardé par décret responsable de la 'lutte antiterroriste', et il déteste être assimilé à un simple mercenaire. Son employeur n'a guère de difficultés pour rémunérer ses services: selon le dernier rapport des Nations unies, la Centrafrique est un pays de transit du trafic organisé autour du pillage des ressources du Congo.", Le Figaro, 19 November 2002.

26 Agence Centrafricaine de Presse, 9 December 2006. On December 10 the same source issued the message that calm had been restored in the PK 12 neighborhood, but added the information "Il convient de rappeler que tout a commencé jeudi soir dernier lorsqu'une foule en colère a lapidé à mort un élément tchadien de la sécurité présidentielle qui venait de poignarder un officier de gendarmerie."

27 In an interview with Le Monde (November 19, 2007), Bozizé acknowledged the presence of Chadian and South African security personnel and gave partly diverging figures: "les Sud-Africains (pas plus d'une cinquantaine d'hommes) et les Tchadiens (trente hommes) assurent ma sécurité rapprochée. Je préférerais faire appel à des Centrafricains mais nous avons connu de tels soubresauts, traversé tant de mutineries, que c'est impossible."

28 La Lettre du Continent, 13 September 2007.

29 www.un.org/depts/DPKO/Missions/minurcaM.htm (access 18 June 2008). 
subregional peacekeeping force established in December 2002 (Force Multinationale en Centrafrique, FOMUC), as one of its original attributions, was to guarantee the security of President Patassé. It could not prevent the successful conquest of Bangui by Bozizé's men in March 2003 (while Patassé was abroad). The renewed mandate did not contain anymore provisions regarding the personal protection of top politicians. ${ }^{30}$

\section{Côte d'Ivoire}

\section{Elite Security Needs}

Côte d'Ivoire was for a long time an extraordinary example of regime stability in West Africa. The state was hierarchically organized. A couple of plot plans, invented or real, were reported during the reign of founding father Félix Houphouët-Boigny, and the first alleged coup attempts were recorded in 1962 and 1963. In 1970, Kragbe Gnagbé, who wanted to run for the presidency, was prohibited from standing and led a rebellion in the heartland of the Bété. The geographically limited rebellion was crushed and he and his core followers were killed by the army. The year 1973 saw another alleged coup attempt. ${ }^{31}$ Critical elite members were arbitrarily arrested without being harmed physically; the founder of the Front Populaire Ivoirien (FPI), Laurent Gbagbo, had this experience several times and exiled himself to Burkina Faso and France. A number of mutinies were recorded during the 1990s, but none led to widespread violence. The very popular "Christmas coup" by Gen. Robert Guéi in 1999 was a bloodless one. This means that the country entered the cycle of deadly violence rather late. But once it did, the pace of events accelerated: mutinies and rumors of and attempted coups multiplied beginning in 2000. On September 18, 2000, gunfire was heard near Guéi's residence. As Guéi's horse was killed during these hours, the event was later termed "the Plot of the White Horse," but there are numerous indications that the general had made up the whole event, not least to get rid of his fellow junta colleagues Palenfo and Coulibaly. Palenfo's closest aides were murdered. To some extent, the following crackdown on Northern officers was the starting point of the later rebellion, as some of those arrested and tortured later became commanders of the armed rebellion, for instance, Chérif Ousmane (later commander of Bouaké) and Ouattara Siaka alias Wattao (deputy chief -of staff of the armed forces of the rebel Forces Nouvelles/FN). ${ }^{32}$ The "Plot of the Black Mercedes" followed in January 2001, this time against newly elected President Gbagbo. Whether it was invented or not is disputed. However, it led to another crackdown in the military apparatus, forcing other Northern officers to flee into exile, mostly to Burkina Faso.

30 www.cemac.cf/TextesOfficiels/Actes/ACTEA07_2006.pdf (access 18 June 2008).

31 For a brief chronological account www.etat.sciencespobordeaux.fr/_anglais/chronologie/ivorycoast.html (access 18 May 2008).

32 Balint-Kurti 2007: 11. 
Balla Keita, a controversial former minister under Houphouët-Boigny and secretary-general of Guéi's party UDPCI, had also fled to Burkina in 2000. He was assassinated in Ouagadougou in August 2002, either by Ivorian security agents or the host governmentthe circumstances have not yet been fully elucidated. ${ }^{33}$

The September 19, 2002 attack on Abidjan resulted not only in numerous "ordinary" casualties but also in the murder of Interior Minister Boga Doudou, while Defense Minister Lida Kouassi was able to escape an attack on his house. In the course of the event, former president Robert Guéi was assassinated, probably in a retaliation act by death squadrons close to President Gbagbo. Death squads continued to operate in what was a climate of terror. However, it should not be forgotten that the rebellion was an attempt to remove the Ivorian government by force and could well be interpreted as life-threatening by the elites in power.

Several assassination attempts were made against rebel leader Soro in the post-2002 period. The first attempt on his life occurred when he was minister of communication and "young patriots" stormed the radio and television buildingon June 27, 2003. ${ }^{34}$ A confirmed second attempt was made by forces close to excluded rebel leader and rival Ibrahim Coulibaly ("IB") on June 20, 2004. They attacked Soro's convoy as it was heading from Korhogo to Bouaké. $^{35}$ And finally, his plane was shot at on June 29, 2007; four of his aides were killed, but Soro remained unharmed. Therefore, it does not come as a surprise that FN leaders had a true security paranoia. The refusal of rebel ministers, for security reasons, to take part in cabinet sessions that were to be held in notoriously unsafe Abidjan is understandable. It is noteworthy that IB was later prosecuted, arrested, and condemned in 2008 to a four-year prison term in France for a coup attempt he was believed to have planned against the Gbagbo government in 2003 using French mercenaries.

But apart from the immediate political elite, further elite circles had reason to fear for their lives: On June 29, 2005, three high-ranking army officers were beaten up by security forces as they were leaving a reception at the French embassy. One of them, Col. Bakassa Traoré, died of a heart attack a few days later (Losch 2006: 67). In August 2005, in an open letter to several newspapers, Col. Jules Yao Yao, the former spokesperson of the army who went into hiding after his removal from office-he was another victim of the beatings-alleged that the Gbagbo regime was responsible for the activities of death squads and related crimes since the outbreak of the crisis. He went as far as mentioning nine names of death squad members, most of them very close to the inner circle of the regime. ${ }^{36}$ Gen. Mathias Doué, the

33 ICG (28 November 2003: 9f).

34 See First Report of the Secretary-General on the United Nations Mission in Côte d'Ivoire, 8 August 2003, S/2003/801, p.5.

35 See Second Report of the Secretary-General on the United Nations Mission in Côte d'Ivoire, 27 August 2004, S/2004/697, p.7.

36 Le Monde, 17.8.2005. Probably the most prominent victims of deaths squads were Gen. Guéi during the attack of Abidjan; Benoit Dacourey-Tabley, brother of former FPI heavyweight and then FN co-leader Luis Dacoury-Tabley; and the popular comedian and RDR member Camara H. 
chief of staff dismissed in November 2004, also went into hiding. In interviews with French media he supported this claim - not without announcing his own coup plans - and confirmed that he had earlier experienced threats to his life.$-{ }^{37}$ Whatever the credentials of these officers are, in the Ivorian case it clearly makes a great deal of sense to reflect particularly on the threats to the personal security of top military personnel when talking about elite security needs.

\section{Patterns of Elite Exclusion}

No major studies on security provision in Côte d'Ivoire were published during the entire Houphouët era. However, it is safe to assume that only with the third wave of democratization and the open contestation of authoritarian rule did things change fundamentally, including in the security field. This new relevance of security aspects was linked to exclusionary tendencies of the regime. The number of functional elites in the country is likely comparable to that proposed above for Cameroon $(1,200),{ }^{38}$ perhaps with some qualifications regarding the much smaller military apparatus. Intra-elite trust can be considered to have been a major problem of the country since the late 1980s when a) the state no longer had the means to find a well-remunerated job for everybody leaving university and $b$ ) the succession of founding father Houphouët-Boigny drew nearer. Nervousness set in within the elite when he finally died in late 1993. The political duel between Prime Minister Ouattara and Speaker of Parliament Bédié, won by the latter, resulted in the splitting of the ruling party but was handled peacefully. However, a massive aggravation of elite tensions occurred when the radical nationalist ideology "Ivoirité" developed in the mid-1990s. ${ }^{39}$ This ideology provided the background for a distinction between first- and second-class citizens, with Northerners belonging to the second group. Additionally, the right to stand at elections was limited to those candidates who could prove they had Ivorian parents (both father and mother); this was seen as a direct consequence of the "Ivoirité" ideology. The move had a clear exclusionary motivation, and it led to the partly violent "boycott actif" of the 1995 presidential elections by the two major opposition parties, the Rassemblement des Républicains (RDR, Ouattara's party) and the FPI. Both assumed they would be cheated in manipulated elections.

The coup in 1999 can be interpreted in different ways as it developed from a simple mutiny, but it was certainly also the expression of growing distrust inside the country's elite. The opportunity to create a new consensus was missed by Gen. Guéi when he cultivated his own

37 Le Figaro, 22 August 2005, Jeune Afrique, 28 August-3 September 2005, 18-26 August 2006.

38 Given a) the overall population size of about 18 million inhabitants (2007)-Cameroon having equally about 18 million inhabitants - and b) the long-term socioeconomic development, both countries were for decades comparable in their economic development until Côte d'Ivoire entered a crisis phase. Population figures according to Geohive (www.xist.org/cntry/ access 18 Feburary 2008).

39 See: Documents: ivoirité, immigration et nationalité / Curdiphe; Conseil economique et social in: Politique Africaine (2000) 78, 63-93. 
ambitions by further splitting different elite factions soon after he took power. A quick change in government took place and a new anti-Ouattara campaign was launched. A new constitution, approved by referendum, was the legal background for not admitting a number of opposition leaders to run for the presidency. The election was won under chaotic circumstances by Gbagbo (FPI), who nevertheless built a coalition government including members of the former ruling party. The rebellion in September 2002 marked the culmination of intra-elite distrust and resulted in numerous elite assassinations and death threats on different sides of the conflict. Elite accommodation was now a function of the different peace agreements, beginning with the agreement in Marcoussis in January 2003. This meant that state sinecures were extended to "rebel ministers," as well as to the two main opposition parties. Although perhaps not intended to be so, the Gbagbo governments were all rather inclusive, ${ }^{40}$ but the inclusion stopped at this level. The security apparatus, the state media, and the para-state companies were brought under party control.

\section{State Services}

Houphouët-Boigny used the first alleged coup plots in the 1960s as a pretext to create a party militia composed predominantly of ethnic Baoulé kinsmen to maintain order in Abidjan. For his personal protection he established a presidential guard separate from the army. However, these structures did not play a central role in Ivorian politics. When Guéi took over, he established a so-called Red Brigade inside the Republican Guard for his more immediate protection, but apparently for some dirty jobs as well. When Guéi tried to manipulate the outcome of the 2000 presidential elections, FPI sympathizers took to the streets and faced the Red Brigade indiscriminately shooting into the crowd. It is, of course, again highly debatable whether this could be seen as an immediate act of personal protection. Members of the Republican Guard were also active in intimidating journalists under Gbagbo. ${ }^{41}$ On the other hand, ten members of the Republican Guard were arrested in the context of the January 2003 coup attempt. The body was reorganized, new recruits were brought in, and all in all roughly 1,000 members could be counted (1,350 according to The Military Balance 2008). The commander of the body was later cited as one mastermind of the death squads active in Abidjan-not exactly his official role, although related as I have argued. It is, however, significant that Gbagbo could rely on a different formal paramilitary body, the Gendarmerie. During the October 2000 turmoil and later, this important unit of 7,600 men (out of 17,050 security forces in total) proved loyal to the FPI leader.

\footnotetext{
40 For the composition of the frequently reshuffled governments see www.abidjan. net/gouvernement/Gouvern ement.htm. Ouattara's party was represented in Gbagbo's government as of August 2002, before the outbreak of the rebellion.

41 www.freemedia.at/cms/ipi/freedom_detail.html?country=/KW0001/KW0006/KW0151/\&year=2005 (access 16 June 2008).
} 


\section{The Role of Externally Based Elite Protection-Private and Public}

Founding father Félix Houphouët-Boigny relied heavily on French assistance, not least in the security field. In fact, he distrusted his own army and felt better protected by the substantial presence of French troops and the existing defense agreement with Paris. This basically did not change during both his rule and Bédié's. The coup in 1999 had repercussions on the way presidents organized their security. Bédié realized too late that his excessive reliance on French forces for his own security had been overoptimistic. France could probably have saved Bédié's regime (as it did, for example, Chadian President Déby's regime in 2006 and 2007), but it did not. Equally, in the 2002 rebel attack on Abidjan and the following civil war, France did not intervene decisively to crush the rebellion, despite an appeal by President Gbagbo to activate the existing defense agreement (referring to outside intervention by Burkina Faso). Gbagbo's adherents later feared that French troops would even kill Gbagbo during the November 2004 crisis. Whether justified or not, this demonstrated the paranoia surrounding presidential security in Côte d'Ivoire following 1999.

As was the case in CAR, embassies and ambassador's residences proved vital for opposition politicians. More or less expectedly, Bédié fled to the French embassy after the "Christmas coup" in 1999. With the "coup of the White horse" in 2000, junta members Palenfo and Coulibaly were rescued while hiding in the Nigerian embassy. After the outbreak of the rebellion in 2002, Ouattara fled to the residence of the German ambassador next door and was later transferred to the French embassy before being flown out of the country. Bédié fled to the Canadian embassy.

In addition to their own security services, Ivorian presidents did use "security advisors" of different sorts. Paul Barril reportedly created a mysterious "action group" as early as 1988 to protect President Houphouët-Boigny. In 1997 the government daily Fraternité-Matin issued a formal démenti regarding information provided by La Lettre du Continent, according to which Barril had met with a minister and an ambassador to discuss the training of security personnel. Later Bédié reportedly met with Barril; one project allegedly discussed was the integration of traditional Dozo hunters into the presidential guard. ${ }^{42}$ Shortly after the outbreak of the 2002 rebellion, Barril was arrested at the Abidjan airport, after meeting secretly with the defense minister. ${ }^{43}$ The announcement that Barril would be Gbagbo's new security advisor ${ }^{44}$ came therefore as a surprise. It had a particular aftertaste as the former Gendarmerie captain and private security entrepreneur had an established Africa record: in particular, he had worked for Rwanda's ex-president Habyarimana and CAR's President Patassé in 2002 (which did not spare the former his assassination and the latter his overthrow in the following year). Barril was now supposed to build up an intelligence network and to conduct an audit of presidential security in Côte d'Ivoire. Rather obscure

$42 \quad$ La Lettre du Continent, 7 May 1998.

43 AFP, 15 October 2002.

44 According to the RDR newspaper Le Patriote, 10 December 2004. 
was the division of private and public responsibility when 25 French mercenaries were replaced by a mission from the para-state agency CIVI-POL, related to then French interior minister Sarkozy. The retired Gen. Guillou was reportedly in charge of recruiting trainers for Gbagbo's presidential guard ${ }^{45}$-rather surprising news given the Linas-Marcoussis agreement brokered by Paris. Gbagbo also used the services of French arms dealer Robert Montoya. It is obvious that a good number of other private military companies tried to profit from the turmoil in Côte d'Ivoire. Among the foreign personnel listed by a UN group of experts were nationals of Belarus, Bulgaria, France, Israel, the Russian Federation, South Africa, Ukraine, and the United Kingdom who provided services in the area of procurement, training, and maintenance of military equipment. ${ }^{46}$

The United Nations Operation in Côte d'Ivoire (UNOCI) - at 9,168 total strength (military and civilian personnel) in 2008 and with responsibility for "the provision of security for members of the Government of Côte d'Ivoire" in its mandate ${ }^{47}$ - responded to this concern for elite security by creating a 206-strong "Sous-Groupement de Sécurité" in $2004 .{ }^{48}$ In his reports about the mission, the UN Secretary-General constantly referred to the demands for protection by elite members of the society. In 2006 the UNOCI unit provided "close and residence protection to 39 dignitaries, which is over its capacity." ${ }^{49}$ When rebel leader Soro, who was constantly a member of consensus governments, agreed to come back to Abidjan to join a cabinet session after 16 months of absence, he did so only with heavy protection. The return of top opposition politicians Ouattara and Bédié meant additional challenges for this specialized UN corps.

\section{Liberia}

\section{Elite security needs}

The bloody coup by Master Sergeant Samuel K. Doe and a couple of junior officers in 1980 was extremely popular in the provinces-and wreaked havoc in the Liberian elite. President Tolbert was killed during the coup, reportedly by being stabbed 15 times. After a show trial, 13 further key members of government and the administration were executed publicly..$^{50}$ But the military junta lacked the competence to manage the country and soon engaged in bitter

45 La Lettre du Continent, 30 January 2003.

46 Report of the Group of Experts submitted pursuant to paragraph 7 of Security Council resolution 1584 (2005) concerning Côte d'Ivoire (S/2005/699), para. 162-167.

47 www.un.org/Depts/dpko/missions/unoci/mandate.html access 18 June 2008.

48 The UNOCI mandate contained the following formulation: To support, in coordination with the Ivorian and South African authorities, the provision of security for members of the Government of National Reconciliation, UN Security Council, Resolution 1609 (2005), adopted by the Security Council at its 5213rd meeting, on 24 June 2005 (S/RES/1609), para. 21.

49 Seventh progress report of the Secretary-General on the United Nations Mission in Côte d'Ivoire, 3 January 2006, S/2006/2, p.9.

50 An account is given at www.globalsecurity.org/military/library/report/1985/liberia_1_april12coup.htm (access 12 May 2008). A total of 200 casualties were reported during the coup. 
infighting. In 1981 two of the coup leaders were accused of a further coup attempt and were executed. Many decision makers left the country and established themselves elsewhere, often in the United States. Gen. Thomas Quiwonkpa, Commanding General of the Armed Forces of Liberia and believed to be the strongman of the junta, was demoted in 1983 and subsequently charged with an attempt to overthrow Doe's regime. Sensing the danger of falling prey to Doe soon, he fled the country, but he attempted a military comeback on November 12, 1985. He was captured, killed, and allegedly mutilated by soldiers loyal to Doe (Ellis 1999: 60). The Gio ethnic group to which Quiwonkpa belonged was now targeted as part of an orgy of repression (as were the Mano). Elite exclusion translated into the persecution of the ethnic followers of individual elite members. Amos Sawyer, one of the leading opposition politicians in Liberia, was arrested in 1984 for allegedly planning a "socialist" coup. As a popular university professor, he could count on the solidarity of students, who protested against his arrest. As a response, Doe ordered the security forces to storm the university campus. This resulted in rape and violence as immediate consequences and in the sustained demise of the university as the most important recruitment basis of the elite.

After the start of the civil war in 1989, Doe again ordered an orgy of violence against potential conspirators and sympathizers of the main rebel movement, the National Patriotic Front of Liberia (NPFL), in early 1990. A series of beheadings of mostly ethnic Gio was recorded (Ellis 1999: 76f). Doe himself was later murdered by order of defected NPFL rebel leader Prince Johnson. NPFL leader Taylor is held responsible for the atrocious death of the rightful winner of the rigged 1985 elections, Jackson F. Doe (no family ties with Samuel Doe) during the early phase of the war. Taylor apparently feared for his leading position inside the rebellion (Ellis 1999: 85).

During Taylor's reign (from 1997 on) a number of suspicious political assassinations occurred and were invariably attributed to the president himself. Only a month after Taylor's election, on November 3, 1997, opposition leader Samuel Dokie and four of his relatives were arrested by government security forces and subsequently murdered. The elite, or at least those elite members who stayed in Monrovia, must have lived in a constant state of paranoia about being killed during this period. In the end, Taylor's reign was ended from within, but by rebel organizations who had received support from Guinea (Liberians United for Reconciliation and Democracy/LURD) and Côte d'Ivoire (Movement for Democracy in Liberia/MODEL).

Elite security was less of a problem after the peace agreement of 2003. However, a coup plot was uncovered in mid-2007.51 Among those implicated were two retired high-ranking officers and the speaker of the Transitional Legislative Assembly. During the trial, one of the accused, Col. Andrew Dorbor, told the court that a National Security Agency (NSA) officer had asked him to implicate top opposition politicians in the alleged coup plot, including

51 Africa Confidential, 3 August 2007; Sawyer 2008: 178. 
former house speaker Edwin Melvin Snowe; the Liberty Party's standard -bearer, Charles Walker Brumskine; George Weah (Congress for Democratic Change/CDC); and Varney Sherman, standard bearer of the Liberia Action Party (LAP). ${ }^{52}$ However, the credibility of this witness was doubtful. In the end, both officers were acquitted in May 2008. Whatever the truth is, the continuation of extreme distrust among the elite is tangible.

\section{Patterns of Elite Exclusion}

The exact population of Liberia is unknown, but has been variously put at some 3.2 million. With a comparable population to CAR, and an equally bad standard of human development and organizational differentiation, an estimate of 400-500 elite members, as earlier estimated for CAR, may be a fair guess. The exclusion pattern is, however, different and includes security-relevant aspects.

The state of Liberia established itself slowly after independence (1820/1847). The coastal zone around Monrovia was the effective center and control over the hinterland was only gradually organized. A clear split between the so-called Americo-Liberians, returned slaves from the US whose descendants became the political and economic elite of the country, and the rest of the population could be observed. The exclusive rule by a handful of prominent families was as oppressive as colonial rule in neighboring countries and was also heavily resented "from below." The military under President William R. Tolbert (1971-1980) was largely apolitical and constitutionally subordinate to the civilian government. The leading officers were largely of Americo-Liberian background and had family ties to the national leadership. ${ }^{53}$ During the so-called "rice riots" in 1979, the police intervened but the military reportedly refused to move. This was a precursor to the following coup by Doe and others.

Doe recruited members to the security forces along ethnic lines by favoring his fellow Krahn. This was the start of the open ethnicization of the security apparatus. The military regime soon turned out to be as exclusive as the century-old Americo-Liberian domination, ${ }^{54}$ and this was not the least important factor in the start of the civil war in late 1989.

Charles Taylor, the strongest competitor in this civil war and elected president of Liberia from 1997 to 2003 was Americo-Liberian, although from a modest family (Ellis 1999: 67); his coming to power was not interpreted as a revenge act of the old elite. One obvious reason for this was that after 1980 very few Liberians would have dared to call themselves Americo-Liberians. Ethnic identity is subject to construction, and it was wise to belong to just any "indigenous" ethnic group one had family relations with. But how much had really changed? Ellis (1999: 281) notes, "In terms of the elite actors, then, Liberia's civil war resembled nothing so much as the continuation of party politics by other means, with a

\footnotetext{
52 The Analyst, 13 December 2007; www.analystliberia.com/i_was_asked_to_implicate_opposition_leaders_ dec13_07.html (access 12 May 2008).

53 www.globalsecurity.org/military/library/report/1985/liberia_5_militaryandgovt.htm (access 12 May 2008)

54 As Doe predominantly recruited personnel from two Krahn clans, Ellis (1990: 56) notes "Many other Krahns felt just as excluded from power as other Liberians."
} 
remarkable lack of new ideas or new personalities emerging from the turmoil." Still, the style was different. In fact, Taylor was not interested in reestablishing the old rule, but rather his own personalized authority, with a monopoly over the exploitation of the country's resources. The Taylor governments were certainly not inclusive, but a warlord logic, and not a neopatrimonial one, was dominant.

This changed again. The Accra peace agreement of 2003-in contrast to the military victory of Bozizé in CAR in 2003-provided for a transitional government in which many "familiar faces from the war" (Stephen Ellis) had their place, such as Taylor's defense minister Daniel Chea or MODEL leader Thomas Yaya Nimely. One problem was that those people also tended to recruit followers into "their" ministries (as United Nations Mission in Liberia (UNMIL) chief Jacques Klein criticized). Perhaps more problematic was the overall respectfulness of this new elite. For example, the speaker of the Transitional National Assembly, George Dweh (LURD), was widely known for his involvement in death-squad activities during the presidency of Samuel Doe (1980-90)..$^{55}$ Inclusiveness in the name of power-sharing and conflict resolution, more or less imposed from outside, was the order of the day. However, it could hardly be equated with a newfound intra-elite trust.

Overall progress was made in creating trust at the elite level after 2003. Some important steps have been taken, not least the conducting of elections in a respectable way. Still, in late 2005, some elite actors seemed reluctant to accept the outcome of those elections and, more generally, progress towards a republican order. Only after a long period of hesitation did former football star George Weah accept his electoral defeat. ${ }^{56}$ The consequences of the 2005 elections were not better in every respect. Thirty senators and 64 representatives to the lower house of the National Assembly were elected. Among them were again various militia leaders, such as Prince Yormie Johnson, famous for torturing then president Samuel Doe on September 9, 1990 before ordering his assassination. Adolphus Dolo, a former general from Charles Taylor's army was elected senator, as was Jewel Taylor, former wife of Taylor. In the cases of Johnson and Dolo, it might be that voters "responded more to fears of future insecurity than to a sense of gratitude for past services" when electing them (Sawyer 2008: 195). Edwin Snowe, another top aide to Taylor (and son-in-law), made it to the National Assembly and campaigned to become its speaker. ${ }^{57}$ Snowe had served as a managing director of the Liberia Petroleum Refining Company under the transitional government, and was believed to have embezzled a substantial amount of money. A local NGO (Liberians for Transparency and Justice) said in a press release that electing Edwin Snowe as house speaker would "send a signal to the world that the men and women of the new House are nothing but a bunch of fickle, spineless, money-grabbing men and women who stand for

55 Stephen Ellis: Liberia, in: Africa Yearbook 2004, Leiden: Brill 2005, p. 103.

56 Weah had a relative majority in the first round of elections $(28.3 \%)$, but the game of alliances played in favor of Johnson-Sirleaf in the second round (59.4\% against $40.6 \%$ for Weah). See the official results by the National Elections Commission www.necliberia.org/results/ (access 4 January 2006).

57 Stephen Ellis: Liberia, in: Africa Yearbook 2005, Leiden: Brill 2006, p. 107. 
nothing and can fall for anything." 58 This signal was sent: Snowe was elected speaker with an overwhelming majority (48 to 13) in January 2007 when he was under a UN travel ban. ${ }^{59}$ Johnson-Sirleaf's government, announced in January 2006, also brought back some familiar faces, but from an earlier phase of Liberian history. The president herself is a Harvardeducated economist and ex-finance minister under Liberian president William Tolbert. Information Minister Johnny McClain held the same position before the 1980 coup. John D. Woods, was until 1980 and is now again managing director of the Forestry Development Authority. It did not go unnoticed that some of the president's relatives got key positions (National Security Advisor Fomba Sirleaf is a stepson and Interior Minister Ambullai Johnson a cousin). The positive news was that only five ministers came from her own political party, while six came from opposition parties (out of 21). Also remarkable was the appointment of numerous women to top positions. This, at least, could be perceived as a break in continuities. ${ }^{60}$ Johnson-Sirleaf therefore started her presidency on a much more inclusive course than previous regimes.

Some elected legislators did not support the extradition of Charles Taylor from Nigeria to the UN-sponsored Special Court for Sierra Leone where he was indicted, let alone to Liberia-where he committed a whole range of crimes but cannot be indicted yet. One obvious reason was that Taylor had enough information to taint the record of those who collaborated with him. Dolo, Johnson, Snowe, Jewel Taylor-all these people have earned popular mandates, although they have a tainted past. ${ }^{61}$ In fact, this is not so difficult to explain. There is virtually no elite member who has not served in government or the higher administration, including parastatal organizations, in one or more capacities during the last quarter of a century. Nobody is 100 percent clean, otherwise he/she would not have survived. Intimidation may have played a role during the 2005 elections. And some are real heroes of their community, representatives of $a$ people, not the people (Sawyer 2008). What this all means for elite accommodation is that the current post-conflict situation permits a much more broad-based inclusion than previous phases of Liberian history. But trust will need time to settle in.

58 www.liberianobserver.com/news/fullstory.php/aid/1275/Don\%92t_Elect_Snowe_Speaker.html (access 4 January 2006). A World Bank-sponsored course in parliamentary procedures for members of the incoming legislature did not include four of the new lawmakers as they could not travel to Accra, Ghana due to a UN travel restriction. The affected lawmakers included Snowe, Jewel Taylor, Dolo, and another militia general, Kai Farley (MODEL). Source: www.unmil.org/read.asp?newsID=917\&cat=libmedia (access 4 January 2006). The entire travel ban list is reproduced under www.un.org/News/Press/docs/2005/sc8569.doc.htm (access 4 January 2006). One of the major errors in the course of the peace negotiations was obviously not to impede war criminals from standing in elections.

59 One year later he stumbled over a vote of no-confidence, was reinstated by the Supreme Court, but then finally resigned. Some background can be found in Africa Confidential, 2 February 2007.

60 Stephen Ellis: Liberia, in: Africa Yearbook 2006, Leiden: Brill 2007, p.116.

61 There are of course elected legislators with a less intriguing past, and they even form a majority. It will be of interest to see how they interact with their famous / dreaded colleagues. 


\section{State Services}

Liberia shows some remarkable continuity with regard to the state structures responsible for presidential security. The National Security Agency (NSA) was established in 1974 as the government's intelligence service. Doe himself was a member of the presidential guard when he organized the coup in 1980. His own presidential guard numbered around 500 men towards the end of the war. The head of the guard, David Nimley, later became leader of the United Liberation Movement of Liberia for Democracy (ULIMO) rebel group. Charles Taylor was very suspicious about his own security and maintained parallel and competing security services led by rival commanders. ${ }^{62}$ The first battalion of the presidential guard was commanded by his own son Chuckie. In addition to the special branch NSA, a particular Special Security Service (SSS) has existed since 1966. The SSS was created as a special unit to provide for all the security needs of the incumbent president. This included, for example, the physical protection of the president, his/her immediate family, and certain officials and visiting dignitaries, as well as the protection of the executive mansion. In 2005, the transitional government approved a new structure for the SSS and authorized a full strength of 395 members (down from 1,287), including 35 civilian staff. ${ }^{63}$ The transitional government was, however, unable to raise the $\$ 900,000$ required to fund the demobilization of the excess personnel. In the end, 870 SSS officers were deactivated with US financial assistance. ${ }^{64}$ It might be of interest to note that the SSS received mostly a "negative" or "disputed" rating by participants in focus group discussions conducted in 2005 (in the framework of a research project on security perceptions ${ }^{65}$ ), maybe due to its record during the Taylor years. In government and UN circles the belief manifested itself that these existing instruments of "elite security" would not be enough. In March 2007 it was decided that over the next five years, a 500-strong quick-reaction police force, in addition to the 3,500 existing police personnel, would have to be formed. This specialized unit, whose personnel would be drawn initially from the 200-strong Liberian National Police Support Unit, would have "the capacity to respond quickly, efficiently and robustly to major breaches of internal security."66

62 During Stephen Ellis' testimony before the International Court of Justice in The Hague he evoked the "disappearance" of a number of NPFL rival leaders, probably murdered by Taylor. See http://charlestaylortrial.org/2008/01/18/1130-cross-examination-of-prosecution-expert-witness-dr-stephen-elliscontinues/ (access 18 May 2008).

63 UN Security Council: Ninth progress report of the Secretary-General on the United Nations Mission in Liberia (S/2005/764), para. 31, 7 December 2005.

64 UN Security Council: Eleventh progress report of the Secretary-General on the United Nations Mission in Liberia (S/2006/376), para. 21, 9 June 2006.

65 Legitimate oligopolies of violence in Post-conflict societies (Liberia, Sierra Leone), funded by the German Foundation of Peace Research.

66 UN Security Council: Fourteenth progress report of the Secretary-General on the United Nations Mission in Liberia (S/2007/151), para. 20, 15 March 2007. 
The Role of Externally Based Elite Protection-Private and Public

Ellis (1999) alludes several times to the Israeli security advisors to President Doe, who in the end could not prevent his downfall. The US government, on the other hand, was reluctant to engage in presidential or more broad-based elite protection over the entire period of 19802003.

Concerning the security of the current governing elite in Liberia, the ongoing UNMIL mission, one of the most substantial UN missions ever with a maximum strength of 15,000 , seems to be a sufficient guarantee that the current government cannot be toppled by extraconstitutional means, including a military coup, as long as it stays. The UNMIL's mandate includes the provision of security "at key government installations, in particular ports, airports and other vital infrastructure." ${ }^{67}$ A suspect deal between the National Port Authority and the Israel-based enterprise Global Security Services to run the container terminal in Monrovia was noted by Africa Confidential (January 20, 2006).

The kind of outside security devices that some CAR and Côte d'Ivoire presidents enjoyed with the presence of French troops was perhaps also tempting to Liberian elites when they made an offer to the US to harbor the Africa Command (AFRICOM) military headquarters on Liberian territory in summer 2007 (reportedly the only country on the continent to do so). President Johnson-Sirleaf put it differently: "Liberia, the U.S. historic ally, has stood resolutely with the United States, through good times and bad, and is offering its territory as it has done in the past, for the establishment of AFRICOM headquarters." 68 In early 2008 the US government decided to maintain AFRICOM headquarters "for the foreseeable future" in Stuttgart, Germany, without deciding on a permanent location. ${ }^{69}$ In light of the discussions that Liberians had-AFRICOM would actually endanger security by making Liberia a target of terrorist attacks, as well as speculations about the buying of Johnson-Sirleaf's conscience by the US government ${ }^{70}$ - and also in light of the record of the French military presence for regime stability in the subregion, this might not be considered a big loss.

\section{Conclusion}

The elements of interest can be briefly summarized in a synopsis (see Table 1).

67 UN Security Council Resolution 1509 / 2003, 19 September 2003, para. 3c,f,g,i.

68 The News (Monrovia), 6 July 2007 (access via http://allafrica.com/stories/200707060807.html, 18 May 2008.)

69 The "frequently asked questions section" of the AFRICOM homepage attests to irritations about AFRICOM on African soil. See www.africom.mil/africomFAQs.asp (access 18 May 2008).

70 See the blog under www.theperspective.org/ (access 18 May 2008). 
Table 1: Security Relevant Elements in CAR, Côte d'Ivoire, and Liberia

\begin{tabular}{|c|c|c|c|c|}
\hline & $\begin{array}{c}\text { Elite } \\
\text { security needs } \\
\end{array}$ & $\begin{array}{c}\text { Patterns of } \\
\text { elite exclusion }\end{array}$ & State services & $\begin{array}{l}\text { Externally based } \\
\text { elite protection }\end{array}$ \\
\hline CAR & $\begin{array}{l}\text { Very high, } \\
\text { since } 1965\end{array}$ & $\begin{array}{l}\text { Ethnic } \\
\text { homogenization of } \\
\text { the military under } \\
\text { Kolingba, purges of } \\
\text { Yakoma under } \\
\text { Patassé, purges of } \\
\text { Patassé-followers } \\
\text { under Bozizé }\end{array}$ & $\begin{array}{l}\text { Dreaded presidential } \\
\text { guard (different } \\
\text { names), 750-900 } \\
\text { strong }\end{array}$ & $\begin{array}{l}\text { Various explicit } \\
\text { efforts, limited } \\
\text { achievements, } \\
\text { ambivalent French } \\
\text { record (particularly } \\
\text { during coups in } \\
1979,2003 \text { ) }\end{array}$ \\
\hline Côte d'Ivoire & $\begin{array}{l}\text { Very high, } \\
\text { since } 2000\end{array}$ & $\begin{array}{l}\text { Electoral } \\
\text { manipulations since } \\
\text { 1990, sidelining of } \\
\text { Northern elites since } \\
\text { 1995, negotiated } \\
\text { broad-based } \\
\text { coalitions since } 2000\end{array}$ & $\begin{array}{l}\text { Republican Guard, } \\
\text { 1,000-1,350; plus } \\
\text { Gendarmerie ultra- } \\
\text { loyal to Gbagbo, } \\
\text { 7,600 strong }\end{array}$ & $\begin{array}{l}\text { Some explicit efforts, } \\
\text { limited } \\
\text { achievements, } \\
\text { ambivalent French } \\
\text { record }(1999,2002)\end{array}$ \\
\hline Liberia & $\begin{array}{l}\text { Very high, } \\
\text { since 1980; } \\
\text { more secure, } \\
\text { since } 2003\end{array}$ & $\begin{array}{l}\text { Exclusion of } \\
\text { hinterland until } \\
\text { 1980, of Gio and } \\
\text { Mano under Doe, of } \\
\text { Krahn under Taylor; } \\
\text { inclusive governance } \\
\text { since } 2003\end{array}$ & $\begin{array}{l}\text { Competing agencies } \\
\text { since } 1970 \text { s; most } \\
\text { important is SSS, } \\
400-1,300 \text { strong }\end{array}$ & $\begin{array}{l}\text { Israeli security } \\
\text { advisors under Doe, } \\
\text { reluctant US } \\
\text { engagement, } \\
\text { systematic and } \\
\text { efficient UN + US } \\
\text { efforts since } 2003\end{array}$ \\
\hline
\end{tabular}

Source: Author's compilation.

In summary, the long list of assassinations and arbitrary arrests on the one hand, and the equally long list of mutinies, coup plots, and real coups since 1965 on the other makes CAR a nightmare example of elite insecurity since the 1960s, with only short interruptions.

Liberia entered the deadly cycle of violence in full swing in 1980 with a bloody coup and the executions of top politicians. A good number of elites left the country forever or for a long period at that moment, and others during the civil war. Political assassinations were not uncommon under Taylor. The outside-guaranteed peace since 2003, while not providing sufficient security to the ordinary citizen, has proved an important factor of elite security.

Côte d'Ivoire, despite precursor events, was only on a slippery slope from 2000 onwards with elites then constantly fearing for their lives. While the number of victims of the comparatively short civil war is comparatively low, elites were targeted frequently. Official presidential guards were in all cases more effective in repression than in protecting the state's top personnel. The latter was more often left to secret parallel and partly commercial services.

What, then, are the effects of the distinctive factors laid out at the beginning of the paper? Although it was very active in the security field in both CAR and Côte d'Ivoire, France's impact on elite security in these countries looks limited compared to the impact of any such player in Liberia. France was either not able or not willing to prevent successful coups in CAR in 1981 and 2003, and in Côte d'Ivoire in 1999. Its behavior in the Ivorian crisis in 2002 
was ambivalent. The 1979 coup against Bokassa was even instigated by France. France was, however, a crucial actor in bringing down the mutinies in CAR in 1996/97 and in providing military support against rebels in 2006/2007; both rebellions could have caused the downfall of the government in place at the time. Individual politicians owe their life to the proximity of the French embassy and were able to negotiate evacuations after having found refuge there. The psychological asset of having a French base in the country, however, quickly lost its appeal (continent-wide) after the Christmas coup of 1999 in Côte d'Ivoire.

Liberia's governing elite tried to attract similar protection from its "natural" patron, the USA, by offering its soil to host the US Africa Command - to no avail. With regard to the murder of top politicians in 1980 and during the Taylor reign, it could be argued that the absence of options to take refuge in the diplomatic premises of a powerful player may have been harmful to elite security. The reluctance of the USA to play a protective role for Liberia (including its elites) during the darkest days of the republic was deeply resented. The overall record of such "patrons" has to be put in perspective, though, with France's balance sheet being highly ambivalent.

The international engagement factor is more complicated to analyze. A major reduction of elite insecurity was related to the substantial involvement of UN peacekeepers in Liberia in 2003, but earlier interventions by Economic Community of West African States (ECOWAS) and its (armed) monitoring group (ECOMOG) did not bring about the same effect. In relation to the size of the country and its population, the UN, ECOWAS, and French peacekeeping missions in Côte d'Ivoire were rather small. Most acts of elite assassination took place before its deployment. However, some physical attacks on ministers and top military personnel took place in the post-2003 phase and could not be prevented. While the strong international engagement may have prevented worse atrocities, the balance sheet is not easy to establish. In CAR the comparatively short MINURCA mission (1998-2000) engendered a time of relative elite security compared to what was to come after 2001, but its mandate did not cover this aspect of security. The small FOMUC mission was meant to guarantee Patassé's security, but it failed in protecting the regime from being toppled. The relative neglect of the country may have contributed to an atmosphere of impunity during the final phase of Patassé's reign. "Necessary, but most of the time insufficient" for elite security may well be the judgment on the record of international engagement in post-conflict situations.

The comparatively small size of the elite in CAR and Liberia was not helpful in finding appropriate solutions to elite security. Elites in these countries faced insecurity at least as much as those in Côte d'Ivoire. Although the top league of elite members in Côte d'Ivoire represents a rather small number of persons, it appears that the complex personal relationships, including experiences of harassment and betrayal, between those people is a crucial cause of distrust and, hence, elite insecurity. A game-theoretical approach to the emergence and decline of trust over time (Axelrod 1984) would probably be appropriate for 
a deeper analysis, but insights into the actors' motivations for noncooperative behavior are limited in the present case.

For an explorative analysis, some elements of explanation can be evoked. Take Côte d'Ivoire: Gbagbo was arrested several times under Houphouët-Boigny, among others when Ouattara was prime minister (1992). Ouattara was sidelined by Bédié in 1993 and de facto prevented from standing for election in 1995. Guéi was ousted as chief of staff by Bédié in 1995, then toppled Bédié in 1999. Guéi betrayed his main fellow junta members, disqualified Ouattara and Bédié in elections, and finally tried to sideline Gbagbo in 2000. Soro led a rebellion in 2002 after feeling betrayed by Gbagbo in 1997. Gbagbo supported the elements who murdering Guéi and tried to catch Ouattara in 2002. And so forth. The list is endless. A similar list could be established for CAR, with the protagonists Dacko, Kolingba, Patassé, Bozizé as the main actors (Mehler 2005). At least with regard to the three case studies under review here, elite size does not play a major role in determining elite security.

The preceding analysis-based on a qualitative three-case comparison-comes up with some clear findings: It qualifies one factor as unimportant (elite size); one as highly ambivalent (the French factor); and one as a necessary, but insufficient condition for elite security (international engagement). There are other factors which must be more important, but which could only be tested by including more positive cases of relative elite security. The determination of such cases is not simple though. Can we measure elite insecurity? In light of the preceding analysis, this looks complicated. One effort to provide some basis for doing so is the "factionalized elite subindex" of the Failed State Index (2007) created by the US-based Fund for Peace. Two indicators are used for the subindex: "Fragmentation of ruling elites and state institutions along group lines" and "Use of nationalistic political rhetoric by ruling elites, often in terms of communal irredentism, (e.g., a 'greater Serbia') or of communal solidarity (e.g., 'ethnic cleansing' or 'defending the faith')." The index gives very similar ratings to CAR (rank 10, value 9.3) and Côte d'Ivoire (rank 8, value 9.3). ${ }^{71}$ The much better rank and value of Liberia (rank 29, value 8.1.) can only be explained on the basis of rather recent developments after the peace agreement of 2003. But it may also be that the indicators "fragmentation" and "political rhetoric" miss the point. In fact, the countries that have experienced more casualties by political assassination and during coups and coup attempts than Liberia are rare. In contrast, political assassinations are a rather recent, while formative, phenomenon in Côte d'Ivoire. However, although the were already widely used under Houphouët-Boigny, coercive methods went unnoticed. This means that information gathering and interpretation, the building of appropriate indicators, and the creation of an event database allowing for large-N comparison are not simple exercises.

71 The methodology is kind of opaque: a special software indexes and scans "hundreds of thousands of opensource articles and reports" using "a powerful data-collection system that includes international and local media reports and other public documents." www.fundforpeace.org/web/index.php?option=com_content \&task=view\&id=229\&Itemid=366 (access 16 June 2008) 
Other results found here are as follows:

- All in all, the differences in terms of elite security needs - for those in power as well as for alternative elites - are very slim among the cases examined.

- Since all three countries offer a very insecure environment for their elites, it appears understandable that the entire range of reactions (creating personal and parallel security services, cooperating intensely with outsiders and private security companies, self-exile, etc.) can be identified.

- A substantial size and an appropriate mandate for peacekeeping missions may have an impact on elite security.

- The achievements of private security companies, however, appear limited.

- The insistence on the loyalty of presidential guards, which translates into their ethnic homogenization, has fostered rather than ameliorated elite distrust.

Perhaps other factors have still more explanatory value. At least as a context factor, the course of the transition seems to play a role, but might be even more important. The case for observing transition courses and outcomes in order to predict "insecurity traps" is rather simple: 1) In the absence of a level playing field during elections, violence becomes more likely. The experiences of Côte d'Ivoire in the 1990s attest to this, as does the controversial election of Taylor (Liberia) in 1997. 2) If a "historical" change of government is reversed by violent means in only a few months time-as in Burundi in 1993, and as arguably attempted in Côte d'Ivoire in 2002-this is a safe recipe for disaster (or civil war, for that matter). 3) And if correctly elected politicians do not differ from their autocratic predecessors - as in Congo-Brazzaville and CAR-and, additionally, openly persecute the followers of their predecessors, this is a clear invitation to the formerly privileged groups to prepare a coup or rebellion. This emphasizes the importance of exclusionary politics for elite security.

While no blueprint for the way out of the "insecurity trap" can be developed here, it appears that elite exclusion-the main driving force of violent intra-elite competition-cannot simply be reversed by including the formerly excluded into extended governments. This would be tantamount to reproducing a neopatrimonial logic that has already proved to be unsustainable. Trust can only be rebuilt over time, when competing elites believe that the rules of the game are respected by all the main competitors and when institutions prove their functionality (and more than once!). 


\section{Bibliography}

Akindès, Francis 2004: The Roots of the Military-Political Crises in Côte d'Ivoire, Uppsala: Nordiska Afriakinstitutet.

Allen, Chris 1999: Warfare, Endemic Violence \& State Collapse in Africa, in: Review of African Political Economy 81, 367-384.

Axelrod, Robert 1984: The Evolution of Cooperation, New York: Basic Books.

Bauer, Kerstin / Dobler, Gregor 2008: Trust in states, trust without states. How the privatization of security affects social trust (introduction to a planned collective work, draft), Basel.

Bayart, Jean-François 1989: L'Etat en Afrique. La politique du ventre, Paris: Fayard.

Collier, Paul et al. 2003: Breaking the Conflict Trap. Civil War and Development Policy, Washington, D.C.: World Bank.

Daloz, Jean-Pascal (ed.) 1999: Le (non-)renouvellement des elites en Afrique subsaharienne, Bordeaux: Centre d'étude d'Afrique noire.

Ellis, Stephen 1999: The Mask of Anarchy: The Destruction of Liberia and the Religious Dimension of an African Civil War, London: Hurst \& Co.

Ellis, Stephen 2005: Liberia, in: Andreas Mehler, Henning Melber, Klaas van Walreaven (eds.), Africa Yearbook 2004, Leiden: Brill, 101-109.

Ellis, Stephen 2006: Liberia, in: Andreas Mehler, Henning Melber, Klaas van Walreaven (eds.), in: Africa Yearbook 2005, Leiden: Brill, 105-112.

Engel, Ulf / Erdmann, Gero 2007: Neopatrimonialism Reconsidered: Critical Review and Elaboration of an Elusive Concept, in: Journal of Commonwealth and Comparative Studies, 45 (1), 95-119.

Hillebrand, Ernst 1993: Demokratisierung als Eliten-Recycling: Das Beispiel Gabuns, in: Afrika Spectrum, 40 (1), 73-92.

Holmqvist, Caroline 2005: Private security companies: the case for regulation, Stockholm: Stockholm International Peace Research Institute.

International Institute for Strategic Studies 2008: The Military Balance 2008, London: IISS.

International Crisis Group 2007: République Centrafricaine. Anatomie d'un Etat fantôme, Rapport Afrique No. 136, Brussels: ICG.

Lambach, Daniel 2007: Oligopolies of Violence in Post-Conflict Societies, GIGA Working Paper, No. 62, Hamburg: GIGA.

Lemarchand, René / Martin, David 1974: Selective Genocide in Burundi, London: Minority Rights Group.

Losch, Bruno 2006: Côte d'Ivoire, in: Africa Yearbook 2005, Leiden: Brill, 65-74. 
Médard, Jean-François 1977: L’Etat sous-développé au Cameroun, in: Année Africaine 1977, 33-84.

Mehler, Andreas 2005: The shaky foundations, adverse circumstances and limited achievements of democratic transition in the Central African Republic, in: Villalón/VonDoepp 2005, 126-152.

Mkandawire, Thandika 2002: The Terrible toll of post-colonial ,rebel movements' in Africa: towards an explanation of the violence against the peasantry, in: Journal of Modern African Studies 40 (2), 181-215.

Mkutu, Kennedy A. / Sabala, Kizito 2007: Private Security Companies in Kenya and Dilemmas for Security, in: Journal of Contemporary African Studies, 25 (3), 391-416.

Ngayap, Pierre Flambeau 1983: Cameroun: Qui gouverne? De Ahidjo à Biya. L'héritage et l'enjeu, Paris: L'Harmattan.

Ngoupande, Jean-Paul 1997: Chronique de la crise centrafricaine 1976-1997: Le syndrome Barracuda, Paris: L'Harmattan.

Quantin, Patrick 1998: Pour une analyse comparative des élections africaines, in: Politique Africaine 69, 13-26.

Sawyer, Amos 2008: Emerging patterns in Liberia's Post-conflict Politics: Observations from the 2005 Elections, in: African Affairs, 107 (427), 177-199.

Sawyer, Amos 2004: Violent conflicts and governance challenges in West Africa: the case of the Mano River basin area, in: Journal of Modern African Studies, 42 (3), 437-463.

Soro, Guillaume 2005: Pourquoi je suis devenu un rebelle. La Côte d'Ivoire au bord du gouffre, Paris: Hachette Littératures.

Villalón, Leo / VonDoepp, Peter (eds.) 2005: The Fate of Africa's Democratic Experiments. Elites and Institutions, Bloomington: Indiana University Press 2005. 


\section{GIGA Journal Family}

The GIGA journal family is a unique publishing initiative that brings together five international area journals edited by the GIGA German Institute of Global and Area Studies.

The journals are high-standard venues for original research on and empirically sound analysis of contemporary politics, society and the economy in Africa, China, Latin America, the Middle East, and Southeast Asia.

- Africa Spectrum

(3 issues per year)

- Journal of Current Chinese Affairs - China aktuell

(4 issues per year)

- Journal of Current Southeast Asian Affairs

(4 issues per year)

- JPLA - Journal of Politics in Latin America

( 3 issues per year)

Further information at www.giga-hamburg.de/giga-journal-family

Articles also available online

\section{GIGA German Institute of Global and Area Studies}

Leibniz-Institut für Globale und Regionale Studien

Neuer Jungfernstieg 21 - 20354 Hamburg - Germany

Phone: +49 40 42825-594 - Fax: +49 40 42825-547

E-mail: info@giga-hamburg.de

Homepage: www.giga-hamburg.de

Ask for your personal sample copy.

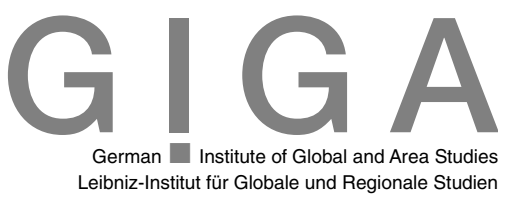




\section{G

\section{Recent Issues}

No 86 Jan Peter Wogart, Gilberto Calcagnotto, Wolfgang Hein, Christian von Soest: AIDS, Access to Medicines, and the Different Roles of the Brazilian and South African Governments in Global Health Governance; September 2008

No 85 Juliane Brach: Constraints to Economic Development and Growth in the Middle East and North Africa; September 2008

No 84 Sebastian Huhn: A History of Nonviolence: Insecurity and the Normative Power of the Imagined in Costa Rica; August 2008

No 83 Andreas Mehler: Not Always in the People's Interest: Power-sharing Arrangements in African Peace Agreements; July 2008

No 82 Dirk Kohnert: EU-African Economic Relations: Continuing Dominance Traded for Aid?; July 2008

No 81 Sebastian Huhn: Discourses on Violence in Costa Rica, El Salvador, and Nicaragua: Social Perceptions in Everyday Life; June 2008

No 80 Peter Peetz: Discourses on Violence in Costa Rica, El Salvador, and Nicaragua: Youth, Crime, and the Responses of the State; June 2008

No 79 Sandra Destradi: Empire, Hegemony, and Leadership: Developing a Research Framework for the Study of Regional Powers; June 2008

No 78 Esther K. Ishengoma and Robert Kappel: Business Constraints and Growth Potential of Micro and Small Manufacturing Enterprises in Uganda; May 2008

No 77 Miriam Prys: Developing a Contextually Relevant Concept of Regional Hegemony: The Case of South Africa, Zimbabwe and "Quiet Diplomacy"; May 2008

No 76 Anika Oettler: Do Qualitative Data Help in Addressing Central American Violence? Research Note on Data Collection; May 2008

No 75 Andreas Mehler, Ulf Engel, Lena Giesbert, Jenny Kuhlmann, Christian von Soest: Structural Stability: On the Prerequisites of Nonviolent Conflict Management; April 2008

No 74 Andreas Ufen: The Evolution of Cleavages in the Indonesian Party System; April 2008

No 73 Thomas Kern and Sang-Hui Nam: Social Movements as Agents of Innovation: Citizen Journalism in South Korea; April 2008

No 72 Peter Peetz: Discourses on Violence in Costa Rica, El Salvador, and Nicaragua: Laws and the Construction of Drug- and Gender-Related Violence; March 2008

All GIGA Working Papers are available free of charge at www.giga-hamburg.de/workingpapers. For any requests please contact: workingpapers@giga-hamburg.de.

Editor of the Working Paper Series: Martin Beck 